\title{
Особливості екологічної ніші молюска Monacha (Monacha) cartusiana (O. F. Muller, 1774) у техноземі на сіро-зеленій глині (Нікопольський марганцеворудний басейн)
}

\section{Дар'я Коваленко}

Мелітопольський державний педагогічний університет імені Богдана Хмельницького, Мелітополь, Україна

Адреса для листування: dashuliakovalenko30@gmail.com

Отримано: 16.03.19; прийнято до друку: 20.04.19; опубліковано: 28.06.19

Резюме. У роботі встановлено особливосто екологічної ніші молюска Monacha (Monacha) cartusiana (O. F. Muller, 1774) у техноземі на сіро-зеленій глині (Нікопольський марганцеворудний басейн) та показано стаціонарність у часі одержаного результату. Дослідження проводили протягом 2012-2014 pp. на ділянці рекультивації Нікопольського марганцеворудного басейну в м. Покров. Як екогеографічні предиктори екологічної ніші молюсків виміряно такі показники, як електропровідність грунту, агрегатний склад, твердість грунту на глибині до 0,5 м, проективне покриття фізіономічних типів рослинності та фітоіндикаційні оцінки екологічних режимів. Для кількісної характеристики екологічної ніші застосовано ENFA-аналіз. У результаті дослідження встановлено, що маргінальність екологічної ніші M. cartusiana визначають такі екогеографічні предиктори, як уміст агрегатів розміром 1-2 та 2-3 мм (позитивна маргінальність) і > 10 мм (негативна маргінальність), твердість грунту на глибинні 0-5, 20-25 та 35-40 см і фізіономічний вигляд рослинного покриву. Цей вид надає перевагу ділянкам із більшим проективним покриттям фізіономічного типу III та уникає ділянок із переважанням фізіономічного типу V і VI. Надають перевагу ділянкам із підвищеною аерацією грунту. Спеціалізацію екологічної ніші M. cartusiana визначають такі екогеографічні предиктори, як уміст агрегатів розміром 0,5-1,0 та > 10 мм, твердість на різних глибинах, електрична провідність грунту, кріоклімат i континентальність, проективне покриття фізіономічних типів III та VI. Установлені особливості екологічної ніші є стаціонарними за період досліджень.

Ключові слова: екологічна ніша, рекультивація, наземні молюски, фактори середовища, фітоіндикація.

\section{The Features of the Land Snail Monacha (Monacha) Cartusiana (O. F. Muller, 1774) Ecological Niche in Technosol on Gray-Green Clay (Nikopol Manganese ore Basin)}

\section{Darya Kovalenko}

Melitopol State Pedagogical University named after Bogdan Khmelnitsky, Melitopol, Ukraine Address for correspondence: dashuliakovalenko30@gmail.com

\footnotetext{
Abstract. The paper deals with features of the Monacha (Monacha) cartusiana (O. F. Muller, 1774) ecological niche in technosols on gray-green clay (Nikopol manganese ore basin) and displayed the stationary at the time of these results. The research was conducted during 2012-2014 years at the remediation site within Nikopol manganese ore basin in city Pokrov. The electrical conductivity of soil, aggregate composition, soil penetration resistance to a depth of $0,5 \mathrm{~m}$, the projective cover physiognomic vegetation types and phytoindication assessment of the environmental regimes were measured as eco-geographic predictors of the ecological niche of the land snail. ENFA- analysis was applied to quantify the characteristics of ecological niche. The electrical conductivity of the sod- lithogenic soil on gray-green clay is $0,67-0,78 \mathrm{MPa} / \mathrm{m}$. Among the 
contents of aggregate fractions dominated sized units $1-2, \ldots, 3-5 \mathrm{~mm}$. The soil penetration resistance of the top layer of sod-lithogenic soil to gray-green clay is $1,62-2,16 \mathrm{MPa}$ and increasing with depth. The sharpest increase in hardness is observed at a depth of 15-20 cm, then the growth of this index is rather moderate. Free from soil surface vegetation is $48,1-53,6 \%$. Most projective cover set for physiognomic type III. The study established that ecological niche marginality of the M. cartusiana is determined by such eco-geographical predictors as content size units 1-2 and 2-3 mm (positive marginality) and $>10 \mathrm{~mm}$ (negative marginality), soil penetration resistance of soil on 0-5, 20-25 and 35-40 cm and physiognomic appearance of vegetation. This species prefers areas with larger projective cover physiognomic type III and avoid areas with a predominance of physiognomic types V and VI. It prefers areas with high soil aeration. Specialization of the M. cartusiana ecological niche is determined by such eco-geographical predictors as content size $0,5-1,0$ units and $>10 \mathrm{~mm}$, soil penetration resistance at different depths, soil electrical conductivity, projective cover of the physiognomic types III and VI. The peculiarities of ecological niches are stationary for a period of research. Clearly, such stability is due to the type of environmental standard space-time regularity environmental regimes in terms of the type technosol. Repeatability of time spatial patterns of edaphic properties can be explained by the formation of soil-like body, which is technosol, system properties. Particularly important plant groups in forming and maintaining regularity in the time of ground structures, which impart soil status due to ecomorphic organizing of the soil body should be noted. Ecomorphic structures can be identified by evaluating the spatial variability of physical properties of soil and vegetation physiognomic features, and environmental assessments of phytoindication modes. These markers can be used to describe the ecological niche of terrestrial molluscs as an eco-geographical predictors of ecological niches. Thus, the spatial patterns of soil properties variability, patterns of variability structure of plant communities thus structuring ecological environment show that this heterogeneity affects the spatial distribution of terrestrial molluscs on the level of individual spatial biogeocoenosis.

Key words: ecological niche, reclamation, terrestrial mollusks, environmental factors, phytoindication.

\section{Вступ}

Фактори довкілля, які впливають на розподіл видів, зазвичай просторово структуровані, тому угруповання мають також просторову структуру [1-3]. Значна частина досліджень стосовно вибору наземними молюсками місцеперебувань, грунтується на порівнянні угруповань молюсків із географічно різних точок відбору проб, які відрізняються рослинним покривом, типом грунтів, рівнем вологості [4-7]. Важливою умовою вивчення екологічного простору є збір множинних даних про його властивості. Нерівномірність розподілу особин пояснюється варіабельністю характеристик середовища, структурною й функціональною строкатістю [8, 9]. 3 едафічних факторів, які впливають на молюсків, найбільш істотними $є$ вміст у грунті кальцію, $\mathrm{pH}$ і механічний склад [10], а також уміст обмінних катіонів та алюмінію [11]. Важливу роль відіграє вологість грунтів [12], однак П. Ондина й співавт. [10] відзначають обмеженість даних щодо ролі вологості грунту в цей момент часу 3 приводу істотної мінливості зазначеного показника. Для розв'язання цієї проблеми адекватне застосування даних фітоіндикації для оцінки аутекологічних особливостей молюсків і структури їх угруповань $[13,14]$. Для опису переважання місцеперебувань молюском Vertigo geyeri Lindholm, 1925 у межах Польщі та Словаччини успішно застосовано фітоіндикаційні шкали Елленберга [15].
Грунтовий покрив $\epsilon$ безперервним утворенням із розвинутою вертикальною й уздовж поверхневою неоднорідністю [16]. Просторова неоднорідність - найважливіша властивість грунту, яка проявляється на різних масштабних рівнях організації педосфери [17, 18]. Дослідження на великомасштабному рівні дали змогу встановити роль у просторовому розміщенні, чисельності та різноманітті угруповань молюсків едафічних факторів [19]. Особливу увагу викликає проблема просторового масштабу й ієрархії діючих на молюсків факторів [20-21].

Оселище характеризується наявністю на деякій території ресурсів та умов для цього виду, у результаті чого стає можливою заселеність цієї території, уключаючи його виживання й розмноження [22]. Мета вивчення вибору місцеперебувань видами полягає у виявленні характеристик навколишнього середовища, які роблять місце придатним для існування виду [23]. Відмінність між місцем життя й не місцем життя $є$ очевидною після порівняння властивостей середовища існування ділянок, де вид знайдено, із ділянками, на яких він відсутній [24]. Однак, як це не пародоксально, але ділянки, де вид відсутній, установити досить складно. Вид на цій ділянці може бути не встановлений через низку причин. Це недосконалість методики обліку або він може бути відсутнім унаслідок історичних причин. Відзначено, що не лише властивості навколишнього середовища можуть визначати місце існування. 
Екологічна ніша - корисна модель для опису
вибору $\quad$ місцеперебувань Дж. Хатчинсоном [25], під фундаментальною екологічною нішею розуміємо весь набір умов, при яких вид може успішно існувати й розмножуватися, а під реалізованою екологічною нішою маємо на увазі положення виду в конкретному угрупованні, де його обмежують складні біоценотичні відносини. Фундаментальна екологічна ніша характеризує потенційні можливості виду, а реалізована - ту їх частину, яка може здійснитися в цих умовах при такій доступності ресурсу. Хатчинсон [25] визначає екологічну нішу як гіперобсяг у багатомірному просторі, зумовленому змінними навколишнього середовища, де вид потенційно може підтримувати життєздатність популяцій. Методично екологічна ніша може бути досліджена засобами загального факторного аналізу системи екологічна нішасередовище (general Niche-environment system factor analysis - GNESFA) [23]. В основу факторного аналізу екологічних ніш покладено припущення про те, що види відносно екогеографічних змінних розподілені невипадково [26]. Певний вид може характеризуватися деякою маргінальністю (яка виражається у відмінності видового середнього від глобального середнього значення екогеографічної змінної) й деякою спеціалізацією (що проявляє себе в тому, що видова дисперсія менша від глобальної дисперсіï).

GNESFA може бути реалізований у вигляді трьох версій - FANTER, ENFA і MADIFA [24]. Факторний аналіз екологічної ніші із середовищем як референтного розподілу (Factor analysis of the niche, taking the environment as the reference - FANTER) розглядає деформацію екологічної ніші щодо екологічного простору, який прийнято як референтне, тобто осі цього простору приводять до такого стану, що екологічний простір має ідеальну сферичну форму. Сферична форма надається екологічній ніші в аналізі MADIFA (Mahalanobis distances factor analysis), а скривлення екологічного простору вказує на ступінь відмінності властивостей середовища від екологічного оптимуму виду. За результатами MADIFA може бути побудована найбільш коректна карта переваги місцеперебувань цим видом [27]. Можливий особливий погляд, за якого два розподіли разом (екологічна ніша й екологічний простір) розкриваються як фокусний та референтний. Ця симетрична думка має перевагу поза вибором референтного розподілу. Цей особливий випадок $\epsilon$ основою факторного аналізу екологічної ніші (Ecological-niche factor analysis - ENFA). В ENFA перша вісь повністю відповідає маргінальності, а наступні осі описують спеціалізацію виду. Інтеграція цих осей також надає можливості побудувати карту переваги місцеперебувань, але, на відміну від MADIFA, цей результат у рамках ENFA не $є$ математичним [24].

Мета роботи - установити особливості екологічної ніші молюска Monacha (Monacha) cartusiana (O. F. Muller, 1774) у техноземі на сіро-зеленій глині (Нікопольський марганцеворудний басейн) та оцінити стаціонарність у часі одержаного результату

\section{Матеріали й методи досліджень}

Дослідження проводили протягом 20122014 pp. на ділянці рекультивації Нікопольського марганцеворудного басейну в м. Покров. Експериментальну ділянку 3 вивчення оптимальних режимів сільськогосподарської рекультивації створено в 1968-1970 pp. на зовнішньому відвалі Запорізького марганцеворудного кар'єру. На ділянці сформовано штучні едафотопи двох типів [28]. Перший - на спланованій суміші розкривних порід із відсипанням на їхню поверхню різних за потужністю шарів чорноземної маси. Другий являв собою сплановані розкривні породи товщиною 2 м, що були винесені 3 різних глибин. Об'єктами дослідження стали обрані дерново-літогенні грунти на червоно-бурих глинах, сіро-зелених глинах, лесоподібних суглинках та педозем (рис. 1). У межах кожного типу техноземів розміщено дослідний полігон, який являє собою регулярну сітку, що складається із сайтів відбору проб розміром $0,5 \times 0,5$ м, відстань між якими становить 3 м і складається із 7 трансект по 15 проб. Відповідно, його розміри становлять $18 \times 42$ м.

Для якісного обліку наземних молюсків, мета якого - складання максимально повних списків видів для певних територій або в певних типах оселищ для дослідження біотопічного розподілу наземних равликів, доцільно оглядати, передусім, місця підвищеної концентрації цих тварин [29, 30]. Кожний сайт у межах досліджених полігонів обстежено тричі на рік: навесні (початок травня), улітку (кінець червня) та восени (наприкінці вересня на початку жовтня) [30]. Перші весняні збори зорієнтовані переважно на добре помітні в цей 
Особливості екологічної ніші молюска Mоnacha (Monacha) cartusiana (O. F. Muller, 1774) у техноземі на сіро-зеленій глині (Нікопольський марганиеворудний басейн)

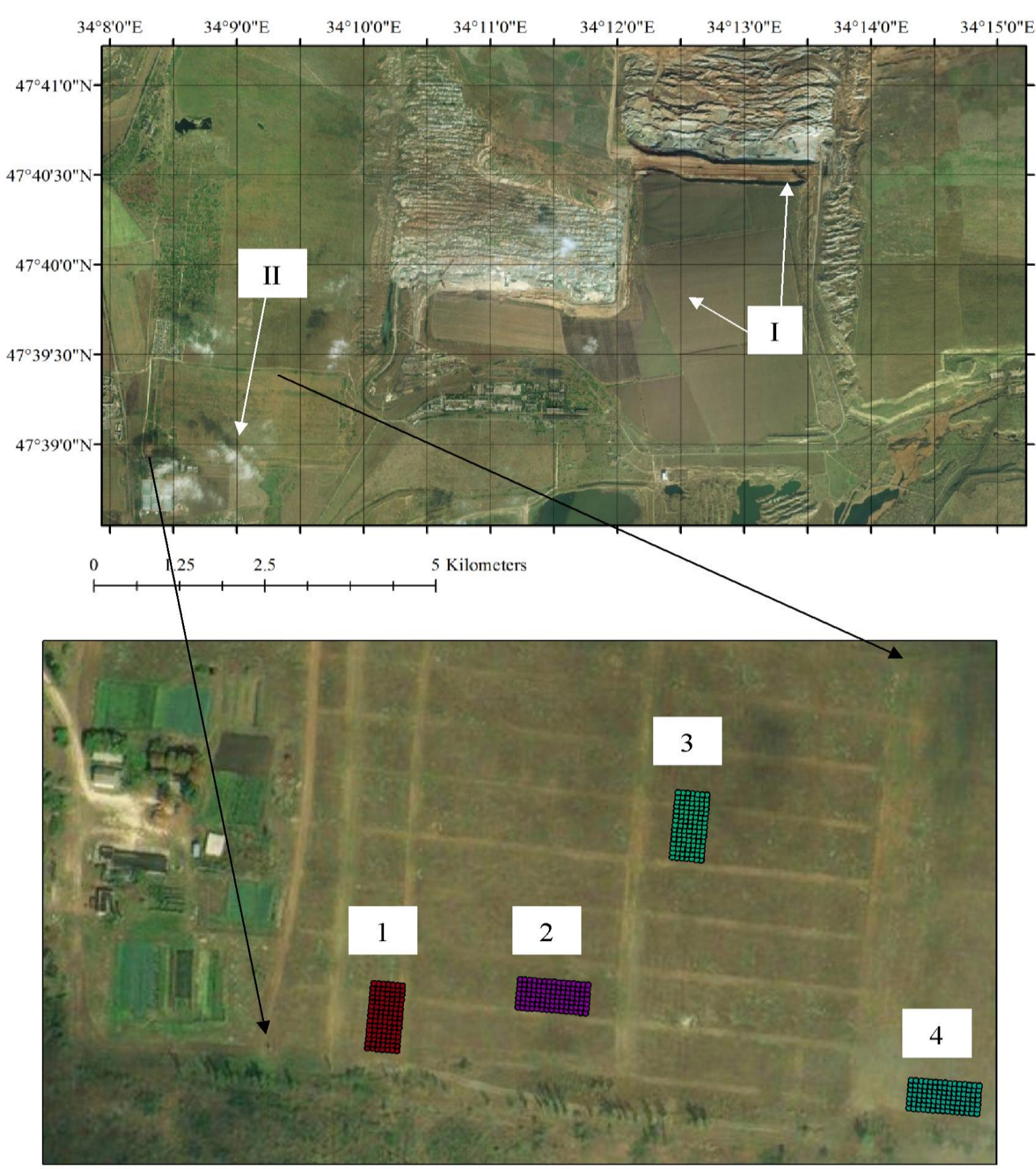

Рис. 1. Розміщення дослідних полігонів у межах Нікопольського марганцеворудного басейну

Примітки. I - Запорізький кар'єр із видобутку марганцевої руди; II - дослідне поле з різними варіантами техноземів: 1 - дерново-літогенний трунт на лесоподібному суглинку; 2 - дерноволітогенний трунт на червоно-бурій глині; 3 - дерново-літогенний трунт на сіро-зеленій глині; 4 - педозем.

період порожні черепашки, наступні на вивчення живих молюсків [31]. Види, які регулярно підніймаються на трав'яні рослини, збирали зранку до висихання роси. Як показав досвід, сприятливою для обліку молюсків $€$ дощова погода, коли багато молюсків виповзає на поверхню грунту та стебла рослин, де їх значно легше помітити та зібрати. У суху пого- ду для пошуків молюсків особливу увагу приділяли різноманітним укриттям (камінню, уламкам гіських порід, великим рослинним залишкам, скупченням органіки в мікропониззях). Молюсків збирали руками. Більшість їх розміщувались у верхньому його шарі.

Для вимірювання твердості використано ручний пенетрометр Eijkelkamp. Це 
портативний пристрій, що складається зі стрижня 1 м завдовжки 3 відмітками через кожні 5 см і Т-подібною ручкою для ручного застосування сили на стрижень. Головною робочою частиною прилада $\epsilon$ плунжер, нагвинчений на нижній кінець штока, який за допомогою рукоятки крізь пружину заштовхується в досліджений грунт. При цьому пружина, що вимірює, стискається пропорційно до величини опору деформації грунту. Дані спостерігаємо безпосередньо й реєструємо вручну. Середня похибка результатів вимірювань прилада становить $\pm 8 \%$. У нашому дослідженні вимірювання твердості грунту зроблено конусом поперечного перерізу $2 \mathrm{~cm}^{2}$ у кожному осередку полігона. Вимірювання електричної провідності грунту (apparent soil electrical conductivity - ECa) за допомогою сенсора НI 76305 (Hanna Instruments, Wood-socket, RI) показали свою значну результативність у проведенні грунтово-екологічних досліджень [32]. Цей сенсор являє собою стальний амперметричний зонд, який може бути уведений безпосередньо в грунт. Він працює разом із портативним приладом НІ 993310.

При фітоіндикаційному оцінюванні шкали наведено за Я. П. Дідухом [33]. До едафічних фітоіндикаційних шкал належать показники гідроморф (Hd), змінності зволоження (fH), аерації (Ае), режиму кислотності (Rc), сольового режиму (Sl), умісту карбонатних солей (Сa), умісту засвоюваних форм азоту (Nt). До кліматичних шкал належать показники терморежиму (Tm), омброрежиму (Om), кріорежиму $(\mathrm{Cr})$ i континентальності клімату
$(\mathrm{Kn})$. Крім зазначених, виділяється ще шкала освітлення (Lc), яку характеризують як мікрокліматичну шкалу. Теплові властивості грунтів індикуються шкалою терморежиму, а гідротермічні - шкалою омброрежиму [34].

\section{Результати}

У досліджених техноземів установлено наявність чотирьох видів наземних молюсків: Brephulopsis cylindrica (Menke, 1828), Monacha (Monacha) cartusiana (O. F. Muller, 1774), Chondrula tridens (O. F. Muller, 1774), Helix (Helix) lucorum Linnaeus, 1758. У цій роботі обговорюємо осбливості екологічної ніші Monacha cartusiana. Чисельність молюска Monacha cartusiana у досліджених біотопах

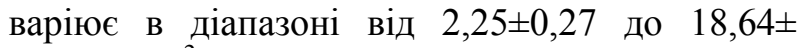
1,08 екз./ м $^{2}$. Чисельність молюсків статистично вірогідно відрізняється між дослідженими типами техноземів (множинний критерій Краскала-Уолліса $H=324,14, p=0,0001)$. Найбільш сприятливі умови для цього виду формуються в дерново-літогенних грунтах на лесоподібних суглинках i на червоно-бурих глинах. Менш сприятливі умови - в біотопах на дерново-літогенних глинах на сіро-зелених глинах, а найбільш екстремальними є педоземи.

Електрична провідність дерново-літогенного грунту на сіро-зеленій глині становить 0,670,78 дСм/м (табл. 1). Серед агрегатних фракцій за вмістом переважають агрегати розміром 1-2, ..., 3-5 мм.

Твердість у верхньому шарі дерноволітогенного грунту на сіро-зеленій глині

Таблиия 1

Статистичні характеристики дерново-літогенного грунту на сіро-зеленій глині $(\mathbf{M} \pm \mathbf{m}, \mathbf{n}=105)$

\begin{tabular}{|c|c|c|c|}
\hline Показник & $2012 \mathrm{p}$. & $2013 \mathrm{p}$. & 2014 p. \\
\hline 1 & 2 & 3 & 4 \\
\hline \multicolumn{4}{|c|}{ Електрична провідність грунту, $\partial C M / м$} \\
\hline $\mathrm{EC}$ & $0,78 \pm 0,03$ & $0,69 \pm 0,02$ & $0,67 \pm 0,01$ \\
\hline \multicolumn{4}{|c|}{ Агрегатна структура, \% фракцій розміром, мм } \\
\hline$>10$ & $10,53 \pm 0,53$ & $10,16 \pm 0,39$ & $10,00 \pm 0,30$ \\
\hline $7-10$ & $7,26 \pm 0,24$ & $7,43 \pm 0,20$ & $5,19 \pm 0,14$ \\
\hline $5-7$ & $8,24 \pm 0,27$ & $7,89 \pm 0,17$ & $7,23 \pm 0,15$ \\
\hline $3-5$ & $18,86 \pm 0,59$ & $19,03 \pm 0,54$ & $19,39 \pm 0,24$ \\
\hline $2-3$ & $22,61 \pm 0,42$ & $27,14 \pm 0,36$ & $27,24 \pm 0,15$ \\
\hline $1-2$ & $18,09 \pm 0,33$ & $14,62 \pm 0,19$ & $14,67 \pm 0,11$ \\
\hline $0,5-1$ & $5,39 \pm 0,22$ & $5,27 \pm 0,18$ & $5,56 \pm 0,11$ \\
\hline $0,25-0,5$ & $5,92 \pm 0,26$ & $5,80 \pm 0,20$ & $7,48 \pm 0,15$ \\
\hline$<0,25$ & $2,69 \pm 0,10$ & $2,65 \pm 0,09$ & $3,54 \pm 0,09$ \\
\hline
\end{tabular}


Особливості екологічної ніші молюска Mопасhа (Monacha) cartusiana (O. F. Muller, 1774) у техноземі на сіро-зеленій глині (Нікопольський марганцеворудний басейн)

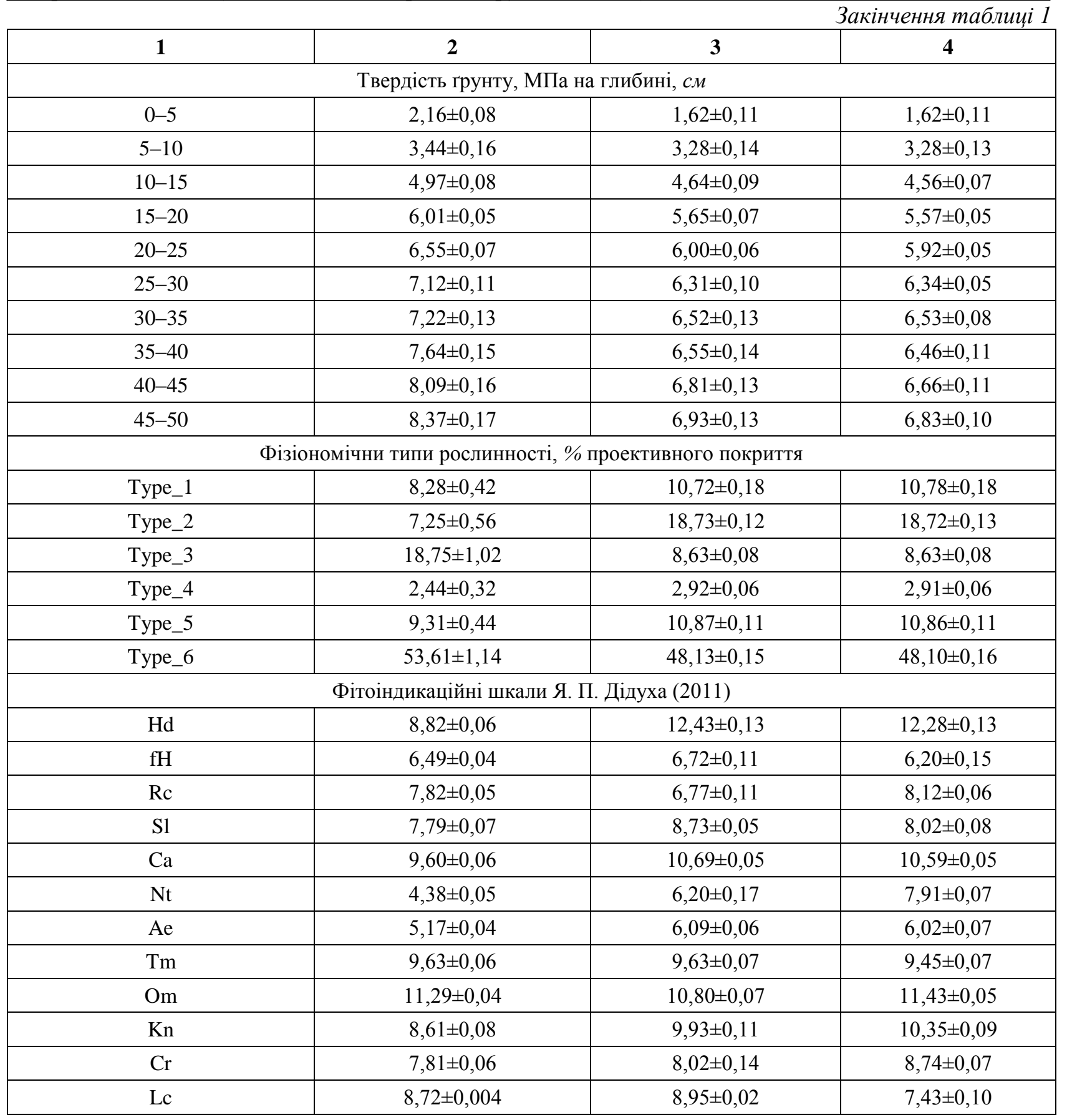

становить 1,62-2,16 МПа та збільшується 3 глибиною. Найбільш різке збільшення твердості спостерігаємо на глибині 15-20 cм, після чого зростання цього показника доволі помірне. Вільна від рослинності поверхня грунту становить 48,1-53,6\%. Найбільше проективне покриття встановлене для фізіономічного типу III.

Фітоіндикаційне оцінювання вказує на те, що режим зволоження дерново-літогенних грунтів на сіро-зеленій глині є сприятливим для субксерофітів, а змінність зволоження - для гемігідроконтрастофобів. Режим кислотності субацидофільний, сольовий режим семіевтрофний. Уміст карбонатів створює умови, які сприятливі для гемікарбонатофілів.
Режим забезпечення технозему засвоюваними формами азоту сприятливий для субанітрофілів. Режим аерації сприятливий для субаерофілів. Режим освітлення такий, який характерний для відкритих просторів. Терморежим - субмезотермний, омброрежим субаридофітний. Загалом фітоіндикаційні оцінки вказують на геміокеанічний клімат із помірними зимами.

Маргінальність екологічної ніші M. cartusiana визначають такі екогеографічні предиктори, як уміст агрегатів розміром 1-2 та 2-3 мм (позитивна маргінальність) $\mathrm{i}>10 \mathrm{мм}$ (негативна маргінальність), твердість грунту на глибинні $0-5, \quad 20-25$ та $35-40$ см і 
фізіономічний вигляд рослинного покриву (табл. 2). Цей вид надає перевагу ділянкам із більшим проективним покриттям фізіономічного типу III та уникають ділянок із переважанням фізіономічного типу V та VI. Надають перевагу ділянкам із підвищеною аерацією грунту. Найбільш сприятливі умови для існування цього виду 3 підвищеними показниками кріоклімату, режимом азотного живлення та кислотністю. Улітку й восени відбуваються лише деякі кількісні зміни характеристики екологічної ніші $M$. cartusiana, a загальні якісні особливості залишаються незмінними. Спеціалізацію екологічної ніші M. cartusiana визначають такі екогеографічні предиктори, як уміст агрегатів розміром 0,5-1,0 та > 10 мм, твердість на різних глибинах, електрична провідність грунту, кріоклімат і континентальність, проективне покриття фізіономічних типів III та VI. Протягом року деякі особливості спеціалізації екологічної ніші M. cartusiana дещо змінюються кількісно, при цьому загальна конфігурація спеціалізація залишається незмінною.

У 2013 р. маргінальність екологічної ніші M. cartusiana досягла максимального значення влітку, а найменшого - восени. Протягом року особливості екологічної ніші характери- зувалися великим рівнем подібності. Молюск M. cartusiana надає перевагу ділянкам iз більшим умістом агрегатів розміром 3-7 мм, із більшими електропровідністю, режимом освітлення та підвищеними характеристиками терморежиму. Вид уникав ділянок із гіпераерацією, підвищеним режимом зволоження й більш високими показниками омброклімату. Також несприятливі умови для M. cartusiana формуються на ділянках iз більшим проективним покриттям фізіономічних типів V та VI.

Найбільш суттєві особливості екологічної ніші молюска $M$. cartusiana полягають у преференції ним мікроділянок із більшим умістом агрегатних фракцій 1-2 та 3-5 мм, більшим проективним покриттям фізіономічних типів I, II й IV (рис. 2). Цей вид уникає порівняно більш зволожених умов із більшою змінністю режиму зволоження грунту. Найчастіше несприятливі умови для M. cartusiana формуються при переважанні проективного покриття фізіономічного типу V та VI. Негативно на цього молюска впливають підвищені показники омброклімату. Ділянки 3 більшим умістом агрегатів $>10$ мм, зазвичай, відрізняються меншою чисельністю M. cartusiana.

Таблиця 2

Характеристики екологічної ніші (маргінальність та спеціалізація) наземного молюска Monacha (Monacha) cartusiana (O. F. Muller, 1774) у межах дерново-літогенних грунтів на сірозелених глинах

\begin{tabular}{|c|c|c|c|c|c|c|}
\hline \multirow{2}{*}{$\begin{array}{c}\text { Екогеографічні } \\
\text { предиктори }\end{array}$} & \multicolumn{2}{|c|}{2012 p. } & \multicolumn{2}{|c|}{2013 p. } & \multicolumn{2}{|c|}{2014 p. } \\
\hline & Mar & Sp & Mar & Sp & Mar & Sp \\
\hline 1 & 2 & 3 & 4 & 5 & 6 & 7 \\
\hline $\mathrm{EC}$ & $-0,01$ & 0,28 & 0,11 & $-0,13$ & $-0,12$ & $-0,06$ \\
\hline \multicolumn{7}{|c|}{ Агрегатна структура, \% фракцій розміром, мм } \\
\hline$>10$ & 0,05 & 0,04 & $-0,31$ & 0,01 & $-0,18$ & 0,13 \\
\hline $7-10$ & 0,07 & 0,07 & $-0,21$ & 0,12 & $-0,15$ & $-0,18$ \\
\hline $5-7$ & 0,10 & $-0,28$ & $-0,17$ & $-0,06$ & 0,03 & 0,01 \\
\hline $3-5$ & 0,27 & $-0,02$ & $-0,13$ & 0,07 & $-0,34$ & $-0,05$ \\
\hline $2-3$ & $-0,31$ & 0,13 & 0,07 & 0,21 & 0,24 & $-0,17$ \\
\hline $1-2$ & 0,27 & $-0,02$ & $-0,13$ & 0,07 & $-0,28$ & $-0,04$ \\
\hline $0,5-1$ & $-0,02$ & $-0,16$ & 0,20 & 0,08 & 0,07 & 0,00 \\
\hline $0,25-0,5$ & $-0,14$ & $-0,08$ & 0,28 & $-0,01$ & 0,02 & $-0,04$ \\
\hline$<0,25$ & $-0,17$ & 0,00 & $-0,09$ & 0,07 & 0,22 & $-0,01$ \\
\hline \multicolumn{7}{|c|}{ Твердість грунту, МПа на глибині, $c м$} \\
\hline $0-5$ & 0,18 & $-0,13$ & $-0,02$ & 0,04 & $-0,07$ & $-0,28$ \\
\hline $5-10$ & $-0,15$ & $-0,02$ & 0,07 & 0,09 & 0,06 & 0,24 \\
\hline $10-15$ & 0,07 & 0,02 & $-0,10$ & 0,01 & 0,06 & $-0,10$ \\
\hline $15-20$ & $-0,18$ & $-0,21$ & $-0,05$ & 0,02 & $-0,17$ & $-0,21$ \\
\hline $20-25$ & 0,21 & $-0,06$ & $-0,10$ & 0,06 & $-0,13$ & 0,15 \\
\hline $25-30$ & 0,00 & 0,22 & $-0,07$ & 0,25 & $-0,18$ & $-0,10$ \\
\hline
\end{tabular}


Особливості екологічної ніші молюска Mоnacha (Monacha) cartusiana (O. F. Muller, 1774) у техноземі на сіро-зеленій глині (Нікопольський марганиеворудний басейн)

\begin{tabular}{|c|c|c|c|c|c|c|}
\hline \multicolumn{7}{|c|}{ Закінчення табличі 2} \\
\hline 1 & 2 & 3 & 4 & 5 & 6 & 7 \\
\hline $30-35$ & 0,04 & $-0,10$ & $-0,25$ & $-0,15$ & $-0,10$ & 0,01 \\
\hline $35-40$ & 0,25 & 0,06 & $-0,29$ & 0,01 & $-0,11$ & 0,05 \\
\hline $40-45$ & 0,02 & $-0,26$ & $-0,03$ & $-0,04$ & $-0,06$ & 0,13 \\
\hline $45-50$ & $-0,05$ & 0,12 & $-0,01$ & $-0,07$ & $-0,25$ & $-0,15$ \\
\hline \multicolumn{7}{|c|}{ Фізіономічні типи рослинності, \% проективного покриття } \\
\hline Type_1 & 0,06 & 0,11 & 0,11 & 0,07 & $-0,03$ & $-0,28$ \\
\hline Type_2 & $-0,04$ & 0,22 & 0,09 & 0,04 & $-0,14$ & 0,20 \\
\hline Type_3 & 0,28 & 0,37 & 0,25 & 0,07 & 0,17 & 0,37 \\
\hline Type_5 & $-0,10$ & $-0,11$ & $-0,23$ & 0,60 & $-0,04$ & $-0,15$ \\
\hline Type_6 & $-0,05$ & 0,39 & $-0,17$ & $-0,09$ & 0,08 & 0,17 \\
\hline \multicolumn{7}{|c|}{ Фітоіндикаційні шкали Я. П. Дідуха (2011) } \\
\hline $\mathrm{Ae}$ & 0,27 & $-0,05$ & $-0,23$ & $-0,13$ & $-0,10$ & 0,03 \\
\hline $\mathrm{Ca}$ & $-0,16$ & 0,07 & 0,05 & 0,16 & 0,13 & $-0,06$ \\
\hline $\mathrm{Cr}$ & 0,29 & $-0,28$ & $-0,15$ & $-0,07$ & $-0,13$ & $-0,15$ \\
\hline EC & $-0,01$ & 0,28 & 0,11 & $-0,13$ & $-0,12$ & $-0,06$ \\
\hline $\mathrm{fH}$ & $-0,24$ & 0,02 & $-0,15$ & 0,01 & $-0,12$ & 0,08 \\
\hline $\mathrm{Hd}$ & $-0,13$ & $-0,07$ & $-0,07$ & 0,03 & $-0,22$ & 0,30 \\
\hline $\mathrm{Kn}$ & $-0,07$ & $-0,24$ & 0,09 & $-0,06$ & 0,07 & 0,20 \\
\hline $\mathrm{Lc}$ & $-0,05$ & 0,04 & 0,27 & 0,33 & 0,34 & 0,02 \\
\hline $\mathrm{Nt}$ & 0,22 & 0,01 & 0,11 & $-0,05$ & 0,24 & $-0,14$ \\
\hline $\mathrm{Om}$ & 0,14 & 0,19 & $-0,07$ & $-0,18$ & 0,14 & $-0,29$ \\
\hline $\mathrm{Rc}$ & 0,18 & 0,12 & $-0,04$ & 0,29 & 0,23 & $-0,14$ \\
\hline $\mathrm{Sl}$ & $-0,03$ & 0,09 & 0,09 & 0,00 & $-0,08$ & $-0,03$ \\
\hline $\mathrm{Tm}$ & 0,11 & $-0,10$ & 0,30 & $-0,17$ & 0,03 & 0,25 \\
\hline
\end{tabular}

\section{Обговорення}

Декілька років поспіль ми відзначаємо подібні патерни структури екологічної ніші

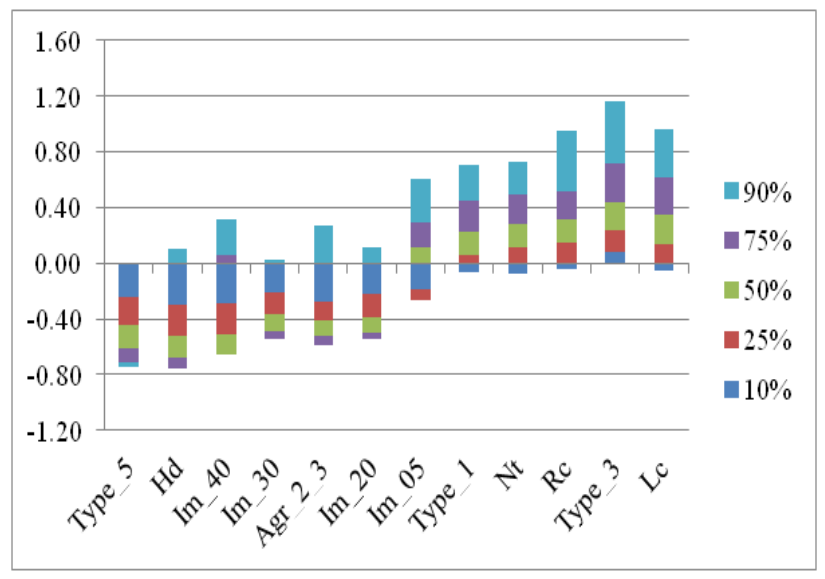

Рис. 2. Параметри маргінальності екологічної ніші для М. cartusiana в межах дерново-літогенних трунтів на сіро-зелених глинах (представлені найбільші та найменші

маркери маргінальності за весь період досліджень; на рисунку показано персентилі варіювання маргінальностей за відповідними ознаками) молюсків у межах біогеоценозу на дерноволітогенних грунтах на сіро-зелених глинах. Очевидно, така стійкість зумовлена екологічним стандартом виду та просторовочасовою регулярністю екологічних режимів в умовах цього типу техноземів. Повторюваність у часі просторових патернів едафічних властивостей зумовлена формуванням у грунтоподібного тіла, яким $\epsilon$ технозем, системних властивостей. Очевидним атрибутом системності $\epsilon$ наявність пам'яті, що й виражається в повторюваності структурноорганізаційних форм технозему. Таким формам можна надати статус грунтових екоморф [35]. Відповідно до уявлень О. Л. Бельгарда [36], екоморфа розкриває взаємозв'язок організмів i середовища та відбиває ступінь їх пристосування до найбільш важливих елементів біогеоценозу. Система екоморф поширена на інших компонентах біогеоценозу [37], що дає підставу інтерпретувати екоморфу як адаптацію біотичної та біокосної компонент біогеоценозу до біогеоценозу в цілому. Адаптивність визначають як реакції різних об'єктів на фактори зовнішнього 
середовища, що проявляє себе в зміні будови й функцій реагуючих об'єктів i їх груп у відповідь на різні мінливі умови, у результаті чого зберігається їх існування [38].

Потрібно відзначити особливо важливу роль рослинного угруповання у формуванні та підтриманні регулярності в часі грунтових структур, яким надають статусу екоморфічної організації грунтового тіла. Екоморфічні структури можуть бути ідентифіковані за допомогою оцінки просторової варіабельності фізичних властивостей грунту та фізіономічних особливостей рослинного покриву, а також фітоіндикаційних оцінок екологічних режимів. Ці маркери можуть бути застосовані для описання екологічної ніші наземних молюсків як екогеографічних предикторів екологічної ніші. Отже, просторові патерни варіабельності грунтових властивостей, патерни мінливості структури рослинного угруповання так структурують екологічне середовище, що ця неоднорідність позначається на просторовому розміщенні наземних молюсків на просторовому рівні окремого біогеоценозу.

\section{Висновок}

Маргінальність екологічної ніші M. cartusiana визначають такі екогеографічні предиктори, як уміст агрегатів розміром 1-2 та 2-3 мм (позитивна маргінальність) i > 10 мм (негативна маргінальність), твердість грунту на глибинні 0-5, 20-25 та 35-40 см i фізіономічний вигляд рослинного покриву. Цей вид надає перевагу ділянкам із більшим проективним покриттям фізіономічного типу III та уникають ділянок із переважанням фізіономічного типу V i VI. Надають перевагу ділянкам із підвищеною аерацією грунту. Спеціалізацію екологічної ніші M. cartusiana визначають такі екогеографічні предиктори, як

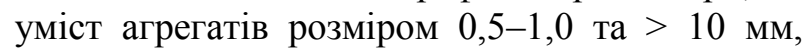
твердість на різних глибинах, електрична провідність грунту, кріоклімат і континентальність, проективне покриття фізіономічних типів III та VI. Установлені особливості екологічної ніші є стаціонарними за період досліджень.

\section{Література}

1. Ettema, C.; Wardle, D. A. Spatial soil ecology. Trends in Ecology, Evolution; 2002, 17(4), 177-183. DOI:https://doi.org/10.1016/S0169-5347(02)02496-5

2. Dray, S.; Pélissier, R.; Couteron, P.; Fortin, M.-J.; Legendre, P.; Peres-Neto, P. R.; Bellier, E.; Bivand, R.; Blanchet, F. G.; De Cáceres, M.;
Dufour, A.-B.; Heegaard, E.; Jombart, T.; Munoz, F.; Oksanen, J.; Thioulouse, J.; Wagner, H. H. Community ecology in the age of multivariate multiscale spatial analysis. Ecological Monographs; 2012, 82, 257-275. https://doi.org/10.1890/11-1183.1

3. Thuiller, W.; Lavorel, S.; Midgley, G.; Lavergne, S. Rebelo, T. Relating plant traits and species distributions along bioclimatic gradients for Leucadendron taxa. Ecology; 2004, 85, 1688-1699.

4. Millar, A. J.; Waite, S. Mollusks in coppice woodland. Journal of Conchology; 1999, 36, 25-48.

5. Martin, K.; Sommer, M. Relationships between land snail assemblage patterns and soil properties in temperate-humid forest ecosystems. Journal of Biogeography; 2004, 31(4), 531-545.

6. Müller, J.; Strätz, C.; Hothorn, T. Habitat factors for land snails in European beech forests with a special focus on coarse woody debris. European Journal of Forest Research; 2005, 124(3), 233-242.

7. Weaver, K. F.; Anderson, T.; Guralnick, R. Combining phylogenetic and ecological niche modeling approaches to determine distribution and historical biogeography of Black Hills mountain snails (Oreohelicidae). Diversity and Distributions; 2006, 12(6), 756-766.

8. Brind'Amour, A.; Boisclair, D.; Dray, Legendre, S. Relationships between species feeding traits and environmental conditions in fish communities: A threematrix. Ecological Applications; 2011, 21, 363-377.

9. McGill, B. J.; Enquist, B. J.; Weiher, E.; Westoby, M. Rebuilding community ecology from functional traits. Trends in Ecology and Evolution; 2006, 21, 178-184.

10. Ondina, P.; Hermida, J.; Outeiro, A.; Mato, S. Relationships between terrestrial gastropod distribution and soil properties in Galicia (NW Spain). Applied Soil Ecology; 2004, 26(1), 1-9.

11. Ondina, P.; Mato, S.; Hermida, J.; Outeiro, A. Importance of soil exchangeable cations and aluminium content on land snail distribution. Applied Soil Ecology; 1998, 9(1), 229-232.

12. Nekola, J. C. Large-scale terrestrial gastropod community composition patterns in the Great Lakes region of North America. Diversity and Distributions; 2003, 9(1), 55-71.

13. Horsák, M.; Hájek, M.; Tichý, L.; Juřičková, L. Plant indicator values as a tool for land mollusc autecology assessment. Acta Oecologica; 2007, 32(2), 161-171.

14. Dvořáková, J.; Horsák, M. Variation of Snail Assemblages in Hay Meadows: Disentangling the Predictive Power of Abiotic Environment and Vegetation. Malacologia; 2012, 55(1), 151-162.

15. Schenková, V.; Horsák, M.; Plesková, Z.; Pawlikowski, P. Habitat preferences and conservation of Vertigo geyeri (Gastropoda: Pulmonata) in Slovakia and Poland. Journal of Molluscan Studies; 2012, 78, 105-111.

16. Самсонова, В. П. (2008). Пространственная изменчивость почвенных свойств: на примере дерново-подзолистых почв. Изд. ЛКИ: Москва; 160 с. 
Особливості екологічної ніші молюска Mоnacha (Monacha) cartusiana (O. F. Muller, 1774) у техноземі на сіро-зеленій глині (Нікопольський марганцеворудний басейн)

17. Медведев, В. В. Неоднородность почв и точное земледелие. Ч. 2. Результаты исследований. Харьков, 2009; 260 с.

18. Медведев, В. В. Неоднородности почв и точное земледелие. Часть 1. Ведение в проблему. Харьков; Изд. 13 тип: 2007; 296 с.

19. Nekola, J. C.; Smith, T. M. Terrestrial gastropod richness patterns in Wisconsin carbonate cliff communities. Malacologia; 1999, 41(1), 253-270.

20. Bohan, D. A.; Raybould, A.; Mulder, C.; Woodward, G.; Tamaddoni-Nezhad, A.; Bluthgen, N.; Pocock, M.J.O.; Muggleton, S.; Evans, D. M.; Astegiano, J.; Massol, F.; Loeuille, N.; Petit. S.; Macfadyen, S. Networking agroecology: integrating the diversity of agroecosystem interactions. Adv. Ecol. Res.; 2013, 49, 1-67.

21. Myšák, J.; Horsák, M.; Svobodová, E.; Cernohorsky, N. Small-scale distribution of terrestrial snaols: patterns of species richness and abundance related to area. J. Mollus. Stud.; 2013, 1-10.

22. Hall, L. S.; Krausman, P. R.; \& Morrison, M. L. The habitat concept and a plea for standard terminology. Wildlife Society Bulletin; 1997, 25(1), 173-182.

23. Calenge, C.; Basille, M. (2008). A general framework for the statistical exploration of the ecological niche. Journal of Theoretical Biology; 1997, 252(4), 674-685.

24. Demidov, A. A.; Kobets, A. S.; Gritsan, Yu. I.; Zhukov, A. V. Spatial agricultural ecology and soil recultivation. Dnepropetrovsk: A. L. Svidler Press., 2013; 560 pp. DOI: 10.13140/RG.2.1.5175.5040

25. Hutchinson, G. E. Concluding remarks. Cold Spring Harbour Symposium on Quantitative Biology; 1957, 22, 415-427.

26. Hirzel A. H.; Guisan A. Which is the optimal sampling strategy for habitat suitability modeling. Ecological Modelling; 2002, 157(2-3), 331-341.

27. Calenge, C.; Darmon, G.; Basille, M.; Loison, A.; Jullien, J. M. The factorial decomposition of the Mahalanobis distances in habitat selection studies. Ecology; 2008, 89, 555-566.

28. Zhukov O. V.; Zadorozhna, G. O.; Maslikova K. P.; Andrusevych K. V.; Lyadskaya I. V. Tehnosols Ecology: Monograph. Dnipro: Zhurfond; 2017, 442 p. (in Ukrainian)
29. Zhukov, O. V.; $\quad$ Yorkina, N. $\quad$ V. Ecotoxicological and malacoindicatic evaluation of the environmental state of surface water currents of the city of Melitopol. Problems of bioindications and ecology; 2017, 22 (1), 143-158.

30. Kunakh, O. N.; Kramarenko, S. S.; Zhukov, A. V.; Kramarenko, A. S.; Yorkina, N. V. Fitting competing models and evaluation model parameters of the abundance distribution of the land snail Vallonia pulchella (Pulmonata, Valloniidae). Regulatory Mechanisms in Biosystems; 2018, 9(2), 198-202. doi:10.15421/021829

31. Balashov, I. A.; Kramarenko, S. S.; Zhukov, A. V.; Shklyaruk, A. N.; Baidashnikov, A. A.; Vasyliuk, A. V. Contribution to the knowledge of terrestrial molluscs in southeastern Ukraine. Malacologica Bohemoslovaca; 2013, 12, 62-69.

32. Zhukov, O. V.; Kunah, O. M.; Taran, V. O.; Lebedinska, M. M. Spatial variability of soils electrical conductivity within arena of the river dnepr valley (territory of the natural reserve «Dniprovsko-Orilsky»). Biological Bulletin of Bogdan Chmelnitskiy Melitopol State Pedagogical University; 2016, 6 (2), 129-157 (in Ukranian). DOI: http://dx.doi.org/10.15421/201646

33. Didukh, Ya. P. The ecological scales for the species of Ukrainian flora and their use in synphytoindication. Phytosociocentre; Kyiv: 2011; 147 pp.

34. Zhukov, A.; Gadorozhnaya, G. Spatial heterogeneity of mechanical impedance of a typical chernozem: the ecological approach. Ekológia (Bratislava); 2016, 35, 263-278. DOI: https://doi.org/10.1515/eko-2016-0021

35. Zhukov, A. V., Zadorozhnaya, G. A. Ecomorphes of the sod-lithogenic soils on reddishbrown clays. Issues of steppe forestry and forest eclamation of soils; 2016, 45, 91-103.

36. Zhukov, A. V. Belgard-Akimov's ecomorphes and ecological matrix. Ecology and bnoospherology; 2010, 21(3-4), 109-111.

37. Zhukov, O. V. The ecomorphic analysis of the soil animals consortia. Svidler press: Dnipropetrovsk; 2006; $180 \mathrm{pp}$.

38. Razumovsky, O. S. Adaptacionizm and behavioural science in the context of the problems of evolution and meaning of life activity. Polignozis; 2003, 2 (22), http://www.polygnozis.ru/default.asp?num= $6 \&$ num $2=132$ 